\title{
The Promotion of Intermodal Transport in Central Europe Through the Design and Realisation of eLogistics Services
}

\author{
Bertram Meimbresse, Gerhard Schilk, Herbert Sonntag
}

\section{Zusammenfassung}

Die Effizienz des Gütertransports ist ein bedeutender Kernpunkt für die Realisierung von Transportströmen zwischen Herstellern und Kunden. Gegenwärtig wird vorzugsweise der Straßengüterverkehr in ganz Europa eingesetzt, was zu enormen negativen Effekten für die Umwelt und die Einwohner führt. Deswegen müssen neue Methoden und Ansätze für einen nachhaltigen Oberflächentransport berücksichtigt werden, wie sie kontinuierlich von der Politik gefordert und zunehmend durch Unternehmen im europäischen Transportsektor akzeptiert werden.

Der intermodale Güterverkehr hat ein entscheidendes Potenzial für eine größere Nachhaltigkeit der Transportprozesse, aber erfordert auch ein größeres Verständnis für die komplexen Zusammenhänge der Prozesse und des Transport-Managements verglichen mit dem monomodalen Verkehr. Die Beherrschung der komplexen und verschiedenen intermodalen Prozesse und Schnittstellen ist der kritischste Faktor bei der Nutzung des intermodalen Verkehrs. Informations- und Kommunikations-Technologien (IKT/ICT), wie IT-Lösungen für strategische Aspekte der Planung von intermodalen Transporten und Promotion der Verkehrsart, können interessierte Transport- und Logistik-Akteure sowie Promotion-Center und Bildungseinrichtungen unterstützen.

Der Artikel beschreibt die Anforderungen solcher IT-Lösungen für den intermodalen Güterverkehr unter Berücksichtigung der Komplexität der TransportKetten. Der entwickelte »Logistics Chain Generator « wird erläutert und mit anderen IT-Tools verglichen. Abschließend werden Schlussfolgerungen hinsichtlich der weiteren Entwicklung dieses spezifischen ITMarktsegmentes gezogen.

\begin{abstract}
The efficient transport of goods is an important issue for realising cargo flows between industries and customers. Nowadays, primarily road transportation is used across Europe leading to tremendous negative side-effects for the environment and European citizens. Therefore new methods and approaches for sustainable surface transport shall be taken into consideration, as continuously promoted by politics and increasingly accepted by commercial enterprises in the European transport sector.

Intermodal transport holds significant potentials for more sustainable transport processes, but requires also a sophisticated understanding of process design and transport management compared with monomodal transport. The handling of complex and divergent intermodal processes and interfaces is the most critical factor for using intermodal transport. Information and Communication Technologies (ICT), such as ITsolutions for strategic aspects of intermodal transport planning and promotion, can help interested transport and logistics users, promotion agencies and educational organisations.

The article describes the needs for such ICT-solutions regarding intermodal transport operations and addresses the complexity of the concerned issue. The developed »Logistics Chain Generator « is introduced and compared with other planning tools. Finally, conclusions are drawn for the further development of this specific ICT market segment.
\end{abstract}

\section{Efficient Goods Transport - an Important Issue for the European Integration}

The European transport and logistics industry holds an important role and accounts for about $7 \%$ of the European GDP and for about $5 \%$ of employment in the European Union (European commission 2006 a). The importance of this industrial sector can be also characterised by its function for the economic growth and prosperity in the European Union. The growth of goods transport within the EU, at a rate of $2.8 \%$ per year, was broadly in line with the economic growth, which was $2.3 \%$ on average in the period 1995 - 2004 (European commission 2006 b). However, when comparing the single goods transport modes (road, rail, inland naviga- 
tion, maritime, and air) a significant unequal allocation and growth can be identified. Reasons for this phenomenon are various, but reflect the current situation of the imbalanced usage of available traffic resources. While road accounts for $44 \%$ of the goods transport market, short sea shipping (SSS) makes up $41 \%$. In contrast to these two dominant modes, rail holds $8 \%$ and inland waterway transport (IWT) about $4 \%$ (European Commission 2001 a). Together with short sea shipping, rail and inland waterway transport constitute the base for sustainable surface transport modes.

The accession of twelve European countries into the European Union in 2004 and 2007 did affect the citizens, economies and the transport industries in all bordering regions. The increased level of economic activities, including trade and investments, produced higher rates of economic growth, whereas growth rates have been still higher in the new EU-Member states and therefore in the whole EU-area (GDP in EU-25 in 2005: $2.3 \%$ ) than in the old EU-Member States (GDP in EU-15 in 2005: 1.5\%) (Eurostat 2006). Simultaneously traffic figures have risen considerably since 2004. But, what more concerns is the circumstance that the balance of transport modes in the new EU member states becomes less reality than in EU-15. Although rail traffic did hold an important role in goods transport in the EU-10/12 this edge did melt continuously since the political changes in Central and South East Europe in 1989. Between 1990 and 1998, road haulage increased by $19.4 \%$ while during the same period, rail haulage decreased by $43.5 \%$ (European commission 2001 b). However, not only the integration of the countries' economies will be a huge challenge for the next future, but also the connection of the traffic systems and transport modes to cover the increased East-West and West-East going cargo flows, which rely on an optimal use of the existing transport system.

Based on the current transport policy of the European Union (White Paper - European transport policy for 2010, European commission 2001 c) adequate measures have to be identified and prepared for implementation. The need for an enhanced integration of transport into a sustainable development is one of the key objectives on tackling future challenges regardless, whether by the enlargement process, by environmental standards or the globalisation. One key issue is the development and promotion of intermodal goods transport.

\section{Intermodal Transport - Chances and Weaknesses}

Intermodal transport systems use generally different modes of transport, e. g. road, railway, inland waterway. To distinguish the different approaches a set of definitions was made (UN/ECE 2001):

- Multimodal transport: Carriage of goods by two or more modes of transport.

- Intermodal transport: The movement of goods in one and the same loading unit or road vehicle, which uses successively two or more modes of transport without handling the goods themselves in changing modes. In the process of intermodal transport normally containers, swap bodies and semi trailers are used. Intermodal transport reached in Europe a market volume of 34.5 billion ton kilometres in 2004. Compared with the complete sum of the inland transport modes road, rail und inland waterway transport the share of intermodal transport on the inland market is rather low (under 2\%) (European Union 2006). The advantage of intermodal transport is the more suitable transport modes for the long range than pure road transport. So transport modes rail and inland waterway can show their potential to carry goods producing a considerable lower emission load. Furthermore, as intermodal transport uses loading units only the transhipment of this (mostly) standardised loading units is necessary to shift the goods efficiently from one mode to the other. But the small market share of intermodal transport poses the question what kinds of factors prevent a higher penetration of the market.

A SWOT-analysis (ECO4LOG 2006 a) identified eight weaknesses $(\mathrm{W})$ of the intermodal transport:

- Difficult international co-operations (W1)

- Terminal and operator cooperation (W2)

- Regular, long-term and big volumes required (W3)

- No intermodal-equipment available (W4)

- Old equipment - infrastructure and rolling stock (W5)

- Uneven utilisation of terminals (W6)

- No single face to the customer $-4^{\text {th }}$ Party Logistics concept (W7)

- Underdeveloped information and communication infrastructure (W8)

To overcome the identified weaknesses six areas for action were identified: Policy, Assets, Business to Business (B2B) Marketing and Promotion, Operations and Processes, ICT (Information and Communications Technology) Requirements, and Education and Training. The interdependencies between the action fields B2B Marketing and ICT Requirements were selected for a closer analysis because these fields have an immediate effect on a better utilization of existing intermodal services and on a higher efficiency of intermodal transport chain (ECO4LOG 2006 b). The analysis shows that the transport industry has always been characterised by its dynamics and openness for innovations. New technologies have already found their way into the European transport industry, where new ICT-based logistics services (e. g. Tracking and Tracing, transport resource planning) have been designed, developed and implemented (ECO4LOG 2005 a).

But end-to-end freight transport planning and monitoring is still a predominant problem in the today's European intermodal transport industry (PriceWaterhouseCoopers 2007). Although appropriate ICT solutions for selected transport chains exist, there is no comprehensive and competitive approach available for intermodal tracking and tracing (T\&T) or intermodal transport planning considering the different actors along the transport chain. Summarizing the situation, the 


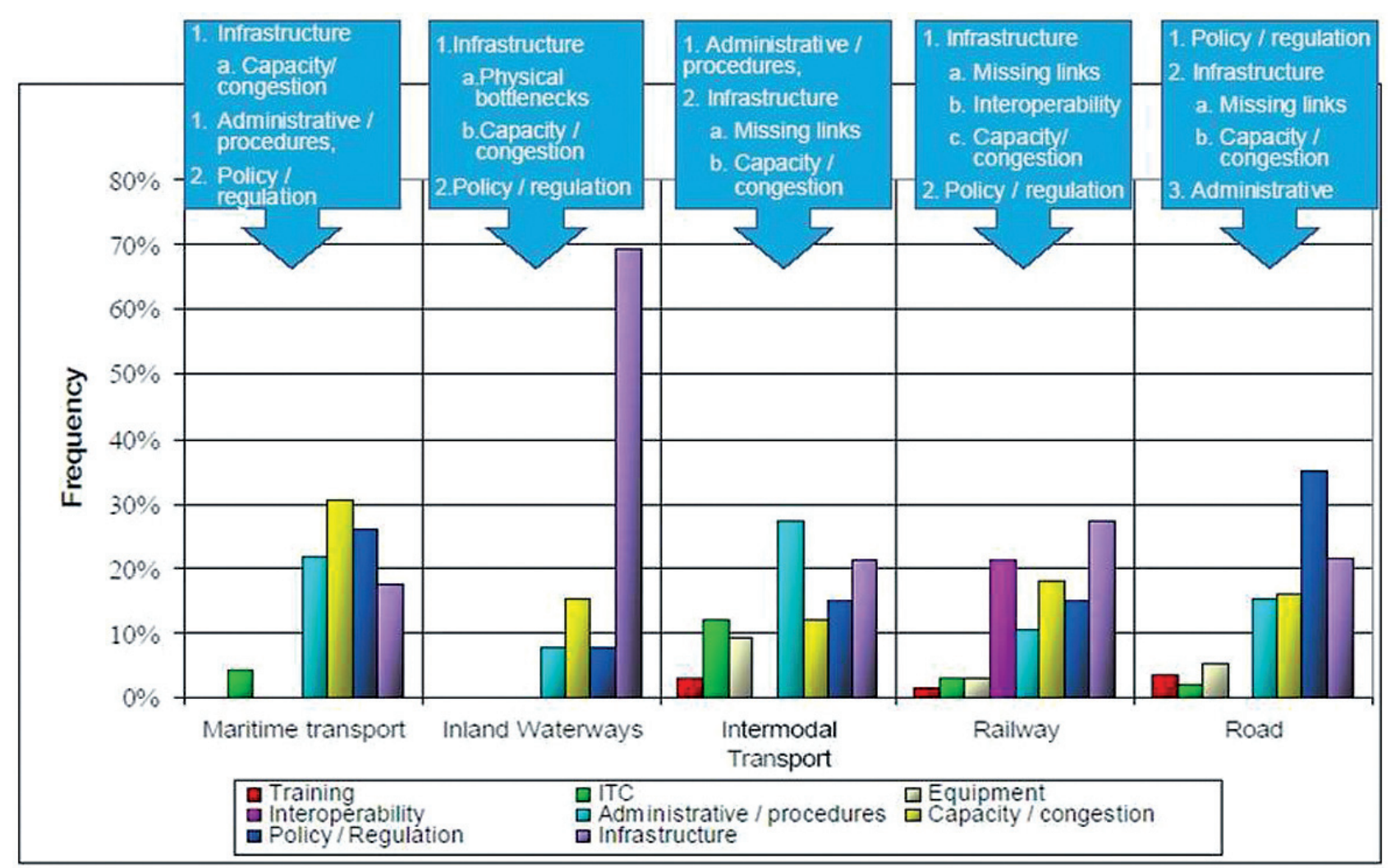

Graphics 1: Stakeholders point of view regarding bottlenecks by transport mode, Source: (PriceWaterhouseCoopers 2007)

European logistics stakeholders identified ICT for intermodal transport as a larger bottleneck than in other fields of transport (see next figure). The stakeholders ranked 5 actions dealing with ICT/intermodal transport and 4 actions dealing with promotion and simplification of multimodal chains among the top 30 actions to improve the European logistics sector sustainable.

Other studies identified the main reasons for problems using ICT in the intermodal transport efficiently. Intermodal transport covers significant more process actors and process interfaces compared to monomodal transport (e.g. door-to-door truck transport). Only if the complete intermodal transport chain is organized by one company, continuous ICT solutions across different transport modes can be found (tradav/ProgTrans 2004).

Some comprehensive (IT) solutions, capable of tracking intermodal transport, however, are available, but mostly in big transport and logistics enterprises so that these represent more ore less in-house/company solutions, which are designed for a dedicated transport chain only. Other transport operators have so far developed and demonstrated new solutions in the framework of research projects. Though, none has reached the way into the intermodal market. So the European Commission states, "many [IT-Projects], [...] have never got beyond the drawing-board or prototype stage (European Commission 2006 d). Therefore, there is no adequate commercial approach and technical solution on the European transport market available capable of easing intermodal transport planning, providing promotion and simplification of the creation of intermodal chains or tracking and tracing intermodal flows en route. The interoperability of IT- and communication systems, planning processes, controlling and safety/security procedures as well as technical equipment is a major prerequisite for the efficient design of intermodal transport chains. Important fields of action with respect to improved co-ordination of information flows in intermodal transport chains were identified as follows (ECO4LOG 2005 b):

- Coordination of common data structures for intermodal handling interfaces between the individual intermodal IT systems

- IT platforms for logistics chain management

- Broker systems for intermodal transport

- Integrated management systems for transhipment terminals

- Terminal information platforms

The transhipment terminals have been identified the as one of the most important chain link in the intermodal transport chain (ECO4LOG 2005 c, European commission 2006 c) because they are the given change nodes (constraints) in the intermodal network. This is true both for the physical goods flows and the connected information flows. Therefore, the following recommendations for better IT integration of terminals including both strategic and operational aspects were given (see next table). The recommendation »Web-based tools for intermodal transport planning and execution « is at least strongly recommended for all types of transhipment terminals. This recommendation is also very close to the identified action fields B2B Marketing/Promotion and ICT Requirements. 


\begin{tabular}{|c|c|c|c|c|}
\hline $\begin{array}{r}\text { Type of } \\
\text { Terminal }\end{array}$ & $\begin{array}{l}\text { Small inland terminal } \\
\text { (small storage cap acities and } \\
\text { intermodality, small resources) }\end{array}$ & $\begin{array}{l}\text { Logistics centre } \\
\text { (relevant storage capacities, } \\
\text { truck/train termodality, averge } \\
\text { resources) }\end{array}$ & $\begin{array}{l}\text { Intermodal Hinterland hub } \\
\text { (extended storage capacities } \\
\text { and intermodality, large re- } \\
\text { sources panel) }\end{array}$ & $\begin{array}{l}\text { Seaport } \\
\text { (extended storage capacities } \\
\text { and intermodality, very large } \\
\text { resources panel) }\end{array}$ \\
\hline \multirow[t]{3}{*}{ Nice to have } & $\begin{array}{l}\text { Resource management systems } \\
\text { at terminal }\end{array}$ & $\begin{array}{l}\text { Mobile Applications and smart } \\
\text { telematics }\end{array}$ & & \\
\hline & $\begin{array}{l}\text { Mobile Applications and smart } \\
\text { telematics }\end{array}$ & & & \\
\hline & $\begin{array}{l}\text { Support for administrative tasks } \\
\text { and commercial settlements }\end{array}$ & & & \\
\hline \multirow[t]{3}{*}{$\begin{array}{l}\text { Strongly } \\
\text { recommended }\end{array}$} & $\begin{array}{l}\text { Web-based tools for intermodal } \\
\text { transport planning and } \\
\text { execution }\end{array}$ & $\begin{array}{l}\text { Resource management systems } \\
\text { at terminal }\end{array}$ & & \\
\hline & & $\begin{array}{l}\text { Web-based tools for intermodal } \\
\text { transport planning and } \\
\text { execution }\end{array}$ & & \\
\hline & & $\begin{array}{l}\text { Support for administrative tasks } \\
\text { and commercial settlements }\end{array}$ & & \\
\hline \multirow[t]{4}{*}{ Necessary } & & & $\begin{array}{l}\text { Resource management systems } \\
\text { at terminal }\end{array}$ & $\begin{array}{l}\text { Resource management systems } \\
\text { at terminal }\end{array}$ \\
\hline & & & $\begin{array}{l}\text { Web-based tools for intermodal } \\
\text { transport planning and } \\
\text { execution }\end{array}$ & $\begin{array}{l}\text { Web-based tools for intermodal } \\
\text { transport planning and } \\
\text { execution }\end{array}$ \\
\hline & & & $\begin{array}{l}\text { Mobile Applications and smart } \\
\text { telematics }\end{array}$ & $\begin{array}{l}\text { Mobile Applications and smart } \\
\text { telematics }\end{array}$ \\
\hline & & & $\begin{array}{l}\text { Support for administrative tasks } \\
\text { and commercial settlements }\end{array}$ & $\begin{array}{l}\text { Support for administrative tasks } \\
\text { and commercial settlements }\end{array}$ \\
\hline
\end{tabular}

Table 1: IT needs according to the type of terminal

\section{Introduction of ECO4LOG's »Logistic Chain Generator«}

The ECO4LOG project aims at improving the interregional co-operation within the field of intermodal goods transport along the axis Germany-Austria-Adria and is part-financed by the European INTERREG programme (see www.eco4log.de). In order to cover the predicted strong increases in goods flows expected in this area, ECO4LOG seeks to strengthen the intermodality by creating new co-operation approaches and information structures. The ECO4LOG area includes DE, PL, AT, HU, SK and SI. Following the analyses carried out regarding weaknesses of intermodal transport - especially underdeveloped ICT - and needs of actors an ICT tool was designed and developed to support the different actors along the intermodal transport chain. The software tool shall provide an information structure and decision support system for users and providers of intermodal transport chains and support the promotion of transhipment terminals as important nodes in the complete transport chain combining physical and information flows. Based on an analysis of current management practices and an outlook on upcoming requirements in this market (ECO4LOG 2005 a), the tool shall complement the shipping and information systems currently used.

Users and planers of intermodal transport services shall be supported by the tool in their strategic planning process by reliable information about intermodal transport facilities in the ECO4LOG area as networks, terminals and providers (ECO4LOG $2005 \mathrm{~d}$ ). The tool shall enable them to choose between alternative transport routes and modes based on decision criteria such as availability of transport/transhipment possibilities and needed additional services, transport time and costs. Contrarily, logistics service providers shall be able to analyze the user's demand regarding transport services and destinations. By that they can improve as well the efficiency as the service quality of intermodal transport chains. So, the tool has the function of an e-Logistics marketplace where the user's demand meets the provider's offer. Finally, the tool shall serve also as a general promotion platform for intermodal transport. The tool contains additional information that is not bound to individual routes or network sections such general traffic conditions and other helpful statements and contacts. In the project's implementation phase the information system covers the regions Germany, BenLux countries, Poland, Czech, Slovakia, Austria, Hungary and Slovenia, but also with links to important North Sea and Adriatic harbours. The central application of the tool is the »Logistics Chain Generator «.

The »Logistics Chain Generator « has the following functions:

- Basic Function: GIS (Geographical Information System) based generation and display of intermodal transport routes on the basis of underlayed networks (road, rail, inland waterway, transhipment terminals) and according to defined criteria and transport requirements (e.g. dangerous goods or 45" containers)

- Alternative Routes Function: Parallel providing and valuing of route-alternatives by criteria: distance, time, costs and energy consumption

- Via-Point Function: Possibility to define 1 or 2 obligatory via-points for the generated transport route in order to prefer specific transport corridors or transhipment terminals 


\begin{tabular}{|l|l|l|l|l|}
\hline & Rail & Inland waterway & Terminals & Logistics Service Provider \\
\hline Technical features & $\begin{array}{l}\text { Gauge Electrification } \\
\text { Allowed speed (max.) } \\
\text { Average speed freight }\end{array}$ & $\begin{array}{l}\text { Waterway class } \\
\text { Average speed }\end{array}$ & $\begin{array}{l}\text { Handled transport units } \\
\text { Handled specific goods } \\
\text { (dangerous, cooled, etc.) } \\
\text { Transhipment equipment }\end{array}$ & $\begin{array}{l}\text { Kind of handled transport units } \\
\text { Kind of handled specific goods }\end{array}$ \\
\hline Capacity features & $\begin{array}{l}\text { No. of tracks } \\
\text { Clearance Capacity (4 levels) }\end{array}$ & $\begin{array}{l}\text { No. of locks } \\
\text { Multilayer of containers }\end{array}$ & $\begin{array}{l}\text { No. of transport units/day } \\
\text { Max. weight handling } \\
\text { Storage capacity }\end{array}$ & $\begin{array}{l}\text { Opening hours } \\
\text { Contacts }\end{array}$ \\
\hline Information features & & $\begin{array}{l}\text { Opening hours } \\
\text { Transport modes }\end{array}$ \\
\hline
\end{tabular}

Table 2: Basic data for the infrastructure and provider database

- Information Function: For each part of the generated transport chains information (contacts, service portfolio) will presented about suitable logistics service providers (e.g. special provider for inland navigation) and transhipment terminals

- Analysis Function: The provider/administrator of the tool can summarise the generated transport chains (anonymized) over a defined time to get information about the demand on intermodal transport.

The complete tool was programmed with SOAP, Web Services, XML and GIS libraries.

The physical network of rail and inland waterway consists of ca. 6,000 network sections rail (only freight sections) and 400 for inland navigation. Network section delimiters are junctions, crossings, transhipment terminals, and changing points of network characteristics (e.g. kind of electrification or number of tracks). For the road network a filtered part of the NAVTEC net (research support license) is used. 210 intermodal terminals and harbours with intermodal capabilities are included. Over 350 intermodal service provider and companies built the data base for the information function. Necessary data were collected from public sources (e. g. research reports, associations, infrastructure providers, own questionnaires). The following table shows the main features of the infrastructure and provider database.

The main administrator of the tool, the Wildau University of Applied Sciences - Research Group Transport Logistics, monitors closely in its day-to-day business major changes in the rail, inland navigation and terminal network as well as in the structure of the provider market. So, the actuality of the data is ensured regarding the requirements for a strategic planning tool and a promotion tool. The main administrator placed an agreement with most of the project partners to update the necessary information from their region each half year, also after the end of the project. In return the contracting project partners can use the tool without restrictions. Since the

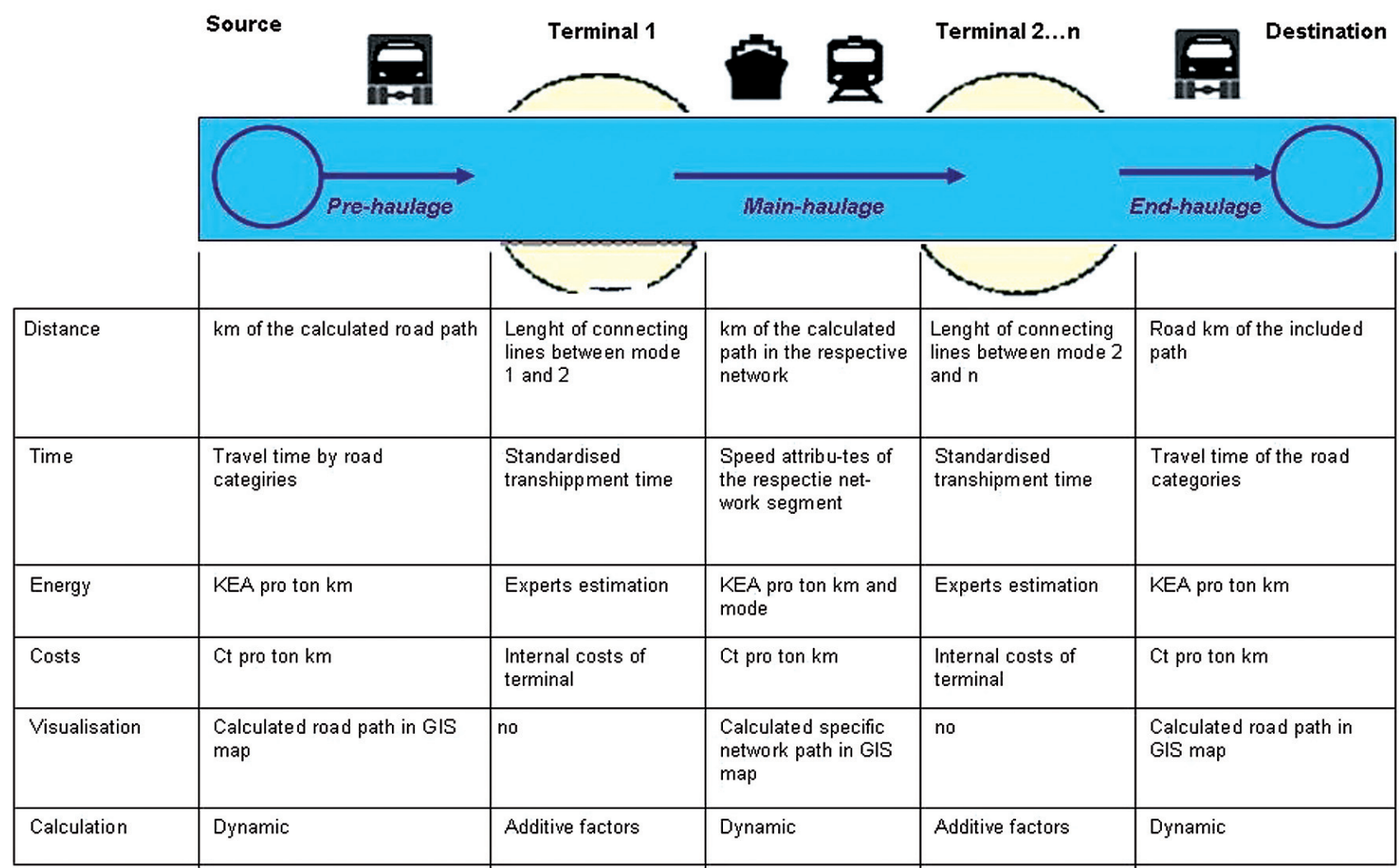

Table 3: Basic data for the Logistics Chain Generator

$K E A=$ Cumulate Energy Consumption, Source: PROBAS database of the German Federal Environment Agency 
road network is based on the always latest version of the NAVTEC net time and effort to hold the complete data up-to-date is manageable.

For the calculation of alternative intermodal routes an iteration free search tree method has been implemented. The algorithm of Dijkstra to calculate the shortest way in the network has been modified in order to consider more than one attribute per network segment (Dijkstra 1959). Transhipment terminals were defined as an additional layer (network with nodes and connecting lines) to connect the different transport networks road, rail and inland waterway transport. The connecting lines represent the transhipment processes. Trough this manipulation the routing algorithm can be extended on the attributes of nodes in a network. To calculate the transhipment process the user is able to define specific values or to use default values. The graphic »Table 3 « depicts the main input values for the generation of alternative intermodal transport chains:

Following this concept the transhipment of certain loading units or goods can be allowed or restricted in each of the terminals reflecting the real situation. Regarding the source and destination points of the transport chain the user can simply select terminals or define the points via an address search in the tool. The table 4 depicts an example of alternative intermodal routes (source/destination: terminal Hamburg Eurokai DE/Ennshafen AT) Results by optimisation criteria:

\begin{tabular}{|c|c|c|c|c|c|}
\hline $\begin{array}{l}\text { Routing } \\
\text { criteria } \\
\text { (Minimum) }\end{array}$ & $\begin{array}{l}\text { Mega- } \\
\text { Joule/ } \\
\text { tkm }\end{array}$ & $\begin{array}{l}\text { Distance } \\
{[\mathrm{km}]}\end{array}$ & $\begin{array}{l}\text { Time } \\
{[d ; h]}\end{array}$ & $\begin{array}{l}\text { Costs } \\
{[\%]}\end{array}$ & Transport Mode \\
\hline $\begin{array}{l}\text { Energy } \\
\text { consumption }\end{array}$ & 588 & 980 & $0 ; 20$ & 122 & Rail direct \\
\hline Distance & 1065 & 829 & $0 ; 19$ & 161 & Road direct \\
\hline \multirow[t]{3}{*}{ Time } & 417 & 606 & $0 ; 09$ & & $\begin{array}{l}\text { Rail from Hamburg } \\
\text { to Nuremberg (DE) }\end{array}$ \\
\hline & 484 & 349 & $0 ; 07$ & & $\begin{array}{l}\text { Road from Nurem- } \\
\text { berg to Enns }\end{array}$ \\
\hline & 901 & 955 & $0 ; 16$ & 151 & Rail-Road \\
\hline \multirow[t]{3}{*}{ Costs } & 489 & 742 & $2 ; 15$ & & $\begin{array}{l}\text { Inland waterway } \\
\text { from Hamburg } \\
\text { to Praha }(\mathrm{CZ})\end{array}$ \\
\hline & 227 & 312 & $0 ; 08$ & & $\begin{array}{l}\text { Rail from Praha } \\
\text { to Enns }\end{array}$ \\
\hline & 716 & 1054 & $2 ; 023$ & 100 & $\begin{array}{l}\text { Inland waterway- } \\
\text { Rail }\end{array}$ \\
\hline
\end{tabular}

Table 4: Example for the results of the Logistics Chain Generator (Italic = parts of the transport chain)

The graphic below depicts the variant »cost minimised routing «. The details given in the lower left table reflect the calculated figures for each part of the intermodal transport chain (rail activated; grey entry). The table under the map contains information about the physical providers of the relevant part like start terminal, suitable service providers for intermodal rail transport in this region, delays on border, end terminal (here rail transport from Praha to Enns). With click on a specific point of the list a context menu provides additional information e.g. contacts, portfolio. Naturally, the terminal and provider information can be viewed separately using the tabs on the left frame.

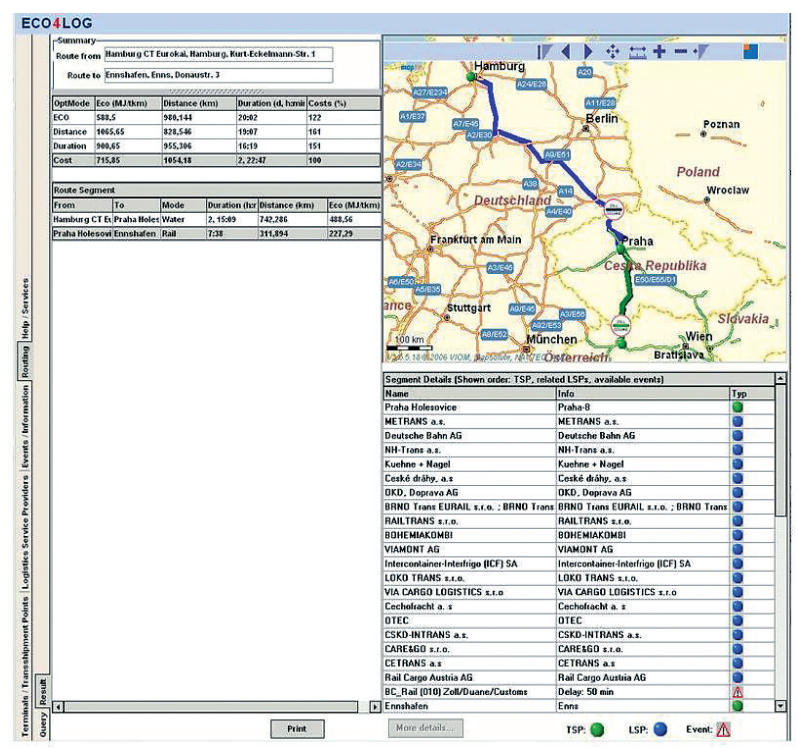

Graphics 2: Example for the results of the Logistics Chain Generator

To calibrate the Logistics Chain Generator known schedules of intermodal transport companies and expert consultations have been used. Over 35 schedules have been analysed. In the framework of ECO4LOG the Logistics Chain Generator was used by partners to develop ideas for new intermodal liner services and to assess their impacts regarding time, costs and energy consumption. It has been used also for the consultancy of shippers to demonstrate possibilities for shifting transport flows towards rail and inland navigation. A substantial part of the users apply the generator for the training of logisticians. The IT tool is currently used by more than 100 intermodal market actors, consultancies and educational organisations across Central Europe.

The aim of the IT tool development was to cover the information gap concerning existing intermodal transport structures as well as intermodal service providers in Central Europe. Furthermore, the tool represents a strategic planning approach for the interregional cooperation. In the follow up project INTERIM (see www. interim-online.eu) possible options to enhance the tool are under discussion and development:

- Routing under consideration of transport quantities to use the economics of scale of rail and inland waterway transport better.

- Geographical enhancement: Western Europe, Scandinavia

- Additional transport mode Short Sea Shipping/Motorways of the Sea

- Consideration of time tables of existing intermodal offers to give the users backbones for the construction of an intermodal transport chain

- Scenario ability to evaluate the effects of changes in the transport networks and the transhipment terminal structure (e. g. Trans European Transport Networks - TEN-T)

- Accessibility and connectivity analyses for and between regions 


\section{Comparison for Strategic Intermodal Planning Tools}

Intermodal transport is characterised by a higher degree of complexity compared with direct road transport. The reasons therefore are various, but the circumstances that more process actors are involved causing significant more processes and interfaces are the most obvious ones. This especially becomes true, when intermodal transport has to compete with door-to-door truck transport operations, where only one dedicated means of transport is being used for one distinctive process scope and geographical region. Thus, on planning and carrying out intermodal transport first more means of transport will be needed for providing both pre- (truck), main- (rail, inland waterway) and end-haulage (truck), which will result in more interfaces, here transhipment terminals, where (un-)loading actions are managed. Besides these main criteria on evaluating ICT-based intermodal transport planning tools $\mathrm{f}$, all other relevant criteria need to be considered, which are used for the validation of supply chain management software as well. This covers the (I) architecture and databases, (II) services and systems and (III) stakeholders and users.

Similar to door-to-door road transport chains, intermodal transport chains need to be planned, before they can be managed and monitored. The higher number of involved market actors and therefore complexity of the processes and interfaces are again the main difference and obstacle, why neither intermodal planning tools nor intermodal tracking and tracing solutions are offered in the European transport market. Therefore, it becomes more obvious that intermodal transport is more difficult both to plan, realise as well as to steer than monomodal transport. By far less ICT-support is nowadays available for planning activities, whereas both resource planning (e.g. yard planning) and brokerage services (e.g. transport brokerage) have found their way into the transport market since the increased penetration of Internet and eBusiness. This means that merely the transport planning and transport monitoring working areas are characterised by a significant lack of ICT-support. While adequate applications are already available for monomodal transport (e.g. map\&guide), meaning mostly for road transport, there has been only a handful comparable ICT-based tools available corresponding to intermodal transport planning needs until now. To compare them the following methodology has been used.

On analysing existing transport planning tools and approaches an adequate methodology is needed enabling further investigations of their individual strengths and weaknesses and benchmarks. Similar to other ITsolutions, IT-based intermodal planning tools comprise an input, throughput and output area.

- Input: Most tools describe their objectives and therefore focussed target group here. Also, the main functions and applications can be seen at this stage, whereas the most important application is the route planning function. Additionally, some tools, like the ECO4LOG tool, offer further applications like transport operator databases, databases covering contact details from terminals and ports, databases on longterm bottlenecks of the traffic infrastructures, databases on administrative contacts and legal documents needed for intermodal transport. The geographical focus is a very important criterion, which physically restricts the operational geographical working area of the dedicated tool. Here, selected tools cover Western European territories (PC-Navigo River Information Service, BintraS, PTV intermodal guide), while others

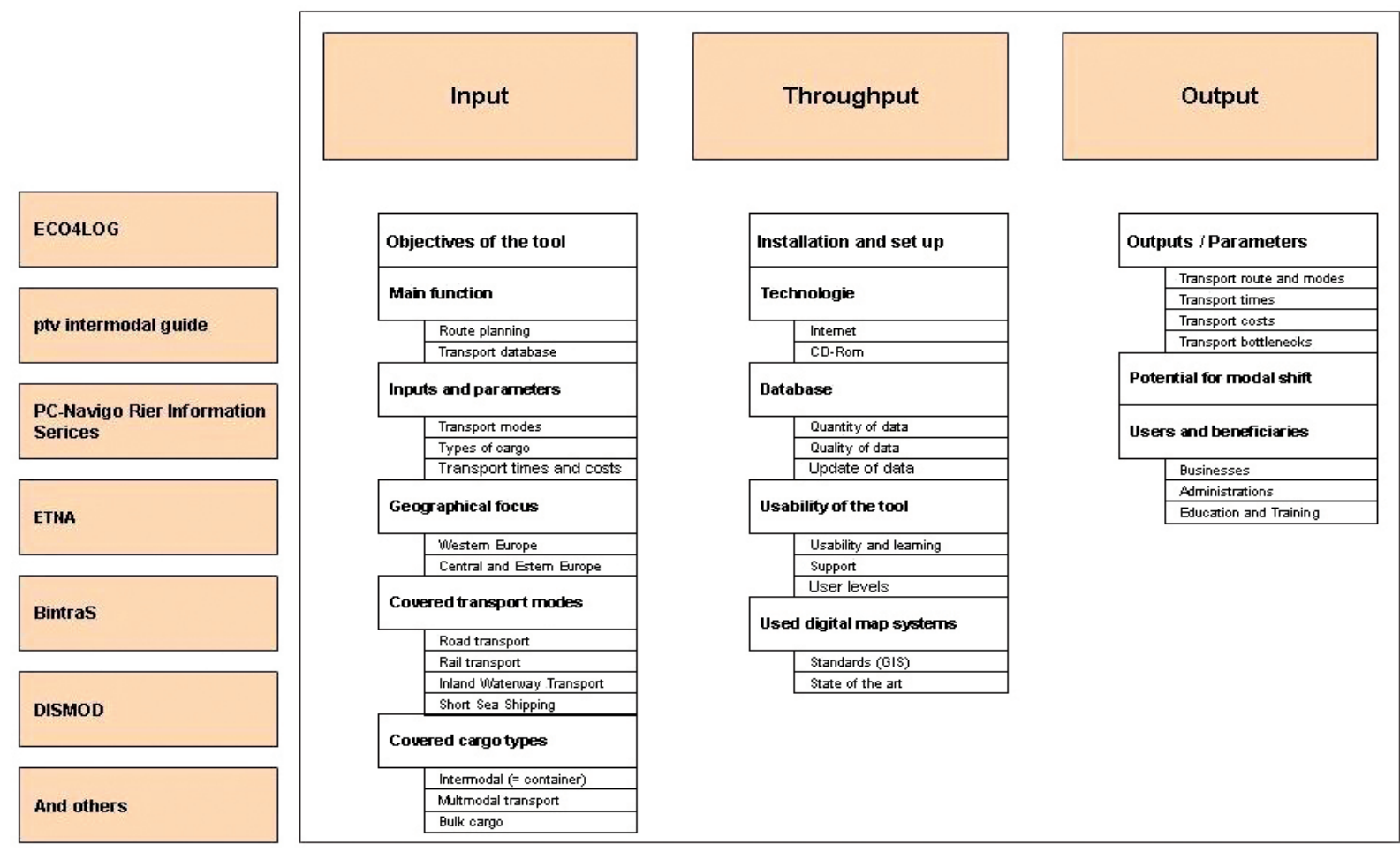

Table 5: Check of ICT-based transport planning tools for generating intermodal transport chains 
cover Eastern European regions (ECO4LOG, ETNA). Also the covered modes of transport in the respective planning tool determine a key criterion for users. There are both intermodal tools (ECO4LOG, PTV intermodal guide, ETNA) available as well as tools that address merely one specific mode of transport like Inland Waterway Transport (PC-Navigo River Information Service, BintraS), whereas these are geographical restricted to Western European waterway corridors (e. g. river Rhine). Besides, also the criterion types of commodities is important for commercial users, as this determines, whether all types of cargoes can be planned or specific ones only, like containers only.

- Throughput: An ease and fast access to the application is the precondition for users' acceptance. Not all of the planning tools make use of the Internet technology and its possibilities to access customers and users directly. A very important issue hereby is the database architecture and concept of the individual application. This includes also the criteria of the quantity (traffic infrastructures, transhipment nodes, transport carriers and many more) and quality (including regular up-dates) of the data and information stored. Last, the used digital map system, normally based on GISstandards, is a key issue, which visualises the transport planning results in forms of graphs and tables.

- Output: All planning tools provide information on the addressed transport modes and regions, when making use of the route planning functions. Almost all, except BintraS, provide its users information about the transport time and duration. But, only few offer transport costs (internal and external costs) as well. Regarding the focussed user group it can be said that there exist mainly three types of stakeholders, which might hold interest in transport planning tools. First, the commercial enterprises located in the transport and logistics industry (e. g. shippers, transport carriers, logistics service providers, terminal and port operators etc.). Second, public administrations (e. g. EC, Ministries, promotion agencies, spatial planning organisations etc.) and third, education and training organisations (e.g. universities, logistics schools,...). Current available approaches (ECO4LOG [http://www. eco4log.de/], ptv intermodal guide [http://www.ptv.de/], BINTRAS [http://www.bintras.de], PC-Navigo River Information Services [http://www.noordersoft.nl/indexde. html], ETNA [http://www.alsodanube.at/], DISMOD [http://www.iml.fraunhofer.de/302.html]) addressing intermodal transport planning have been predominantly developed within research projects, mostly co-financed by European programmes. In this manner the ECO4LOG project has been carried out under the INTERREG programme, the ptv intermodal guide, ETNA and partly PC-Navigo under the $5^{\text {th }}$ Framework Programme (FP5GROWTH). However, until now, only few of them are available for commercial usage like PC-Navigo and BINTRAS, which offer primarily transport planning support for Inland Waterway Transport (IWT) operators rather than for comprehensive intermodal transport chains. All other transport planning tools are still under development are not offered to the European transport market. But with respect to the permanent needed promotion of intermodal transport among market actors, administrations and logistics training organisations it should be questioned whether a public accessible tool is of more importance than a commercial one. The table below shows a qualitative comparison between the tools and gives possible users an impression about the capabilities.

\begin{tabular}{|c|c|c|c|c|c|c|}
\hline & ECO4LOG & ptv intermodal guide & PC-Navigo & BINTRANS & ETNA & DISMOD \\
\hline $\begin{array}{l}\text { Transport } \\
\text { modes }\end{array}$ & $\begin{array}{l}\text { rail, road, inland } \\
\text { navigation }\end{array}$ & $\begin{array}{l}\text { rail, road, inland } \\
\text { navigation }\end{array}$ & inland navigation & inland navigation & $\begin{array}{l}\text { rail, road, inland } \\
\text { navigation }\end{array}$ & $\begin{array}{l}\text { rail, road, inland navi- } \\
\text { gation (only separate } \\
\text { routing per mode) }\end{array}$ \\
\hline $\begin{array}{l}\text { Geographical } \\
\text { coverage }\end{array}$ & $\begin{array}{l}\text { Central Europe: } \\
\text { DE, BeneLux, PL, } \\
\text { SK, CZ, HU, SI, AT }\end{array}$ & complete Europe & complete Europe & $\begin{array}{l}\text { Germany, BeneLux, } \\
\text { links to neighbour- } \\
\text { ing countries }\end{array}$ & complete Europe & $\begin{array}{l}\text { complete Europe } \\
\text { (road) }\end{array}$ \\
\hline GIS application & yes & yes & yes & no & no & yes \\
\hline $\begin{array}{l}\text { Transport } \\
\text { provider } \\
\text { considered }\end{array}$ & yes & no & no & $\begin{array}{l}\text { yes, if located in } \\
\text { harbours }\end{array}$ & yes & no \\
\hline Target group & $\begin{array}{l}\text { logistic providers, } \\
\text { transport chain } \\
\text { planners }\end{array}$ & $\begin{array}{l}\text { logistic providers, } \\
\text { shippers }\end{array}$ & $\begin{array}{l}\text { inland navigation } \\
\text { operators }\end{array}$ & $\begin{array}{l}\text { inland navigation } \\
\text { operators }\end{array}$ & $\begin{array}{l}\text { shippers, logistic } \\
\text { providers }\end{array}$ & shippers \\
\hline $\begin{array}{l}\text { Optimisation } \\
\text { criteria }\end{array}$ & $\begin{array}{l}\text { costs, distance, } \\
\text { time, energy con- } \\
\text { sumption }\end{array}$ & costs, distance, time, & $\begin{array}{l}\text { costs (machine } \\
\text { hours), distance, } \\
\text { time, tourist aspects }\end{array}$ & distance & distance, time & costs \\
\hline $\begin{array}{l}\text { Availability via } \\
\text { Internet }\end{array}$ & yes & no (sales product) & no (sales product) & yes & no & yes \\
\hline $\begin{array}{l}\text { Potential for } \\
\text { modal shift }\end{array}$ & yes & yes & $\begin{array}{l}\text { only towards inland } \\
\text { navigation }\end{array}$ & $\begin{array}{l}\text { only towards inland } \\
\text { navigation }\end{array}$ & yes & $\begin{array}{l}\text { only by comparison of } \\
\text { different routings }\end{array}$ \\
\hline Advantage & $\begin{array}{l}\text { combination of } \\
\text { intermodal routing } \\
\text { results and trans- } \\
\text { port providers }\end{array}$ & $\begin{array}{l}\text { comprehensive cost } \\
\text { functions }\end{array}$ & $\begin{array}{l}\text { detailed nautical } \\
\text { information }\end{array}$ & $\begin{array}{l}\text { quick overview of } \\
\text { inland navigation } \\
\text { possibilities }\end{array}$ & $\begin{array}{l}\text { quick overview of } \\
\text { existing offers }\end{array}$ & $\begin{array}{l}\text { comprehensive cost } \\
\text { functions }\end{array}$ \\
\hline Disadvantage & $\begin{array}{l}\text { geo. coverage is to } \\
\text { small for European } \\
\text { wide applications }\end{array}$ & & monomodal & monomodal & $\begin{array}{l}\text { only relations with } \\
\text { existing intermodal } \\
\text { services/offers }\end{array}$ & $\begin{array}{l}\text { no real consideration } \\
\text { of intermodality }\end{array}$ \\
\hline
\end{tabular}

Table 6: Comparison of ICT-based intermodal transport planning tools 


\section{Conclusions}

Intermodal transport, which is characterised by different transport modes (e. g. road, rail, inland waterway, short sea shipping), numerous business enterprises (e. g. shippers, transport carriers, logistics service providers, terminal/port operators etc.), divergent processes (e. g. transport planning, monitoring) and activities (e.g. transport booking, management of fleet), is a significant more complex transport system than road transport, where trucks are offering direct door-to-door transport. As every transport, also the complex intermodal transport chains have to be planned, managed and monitored. Therefore, it is expected that suitable ICT-systems are in the European transport market available supporting the transport operators. Until now (2007), there are no dominant ICT-systems and services available, neither for easing intermodal transport planning nor for intermodal transport monitoring or promotion.

The current problem is the non-existence of adequate end-to-end freight transport planning and monitoring tools. The preparatory study for an impact assessment on a EU Freight Logistics Action Plan (PriceWaterhouseCoopers 2007) confirms this existing bottleneck in the fields of intermodal transport planning and intermodal transport monitoring and elaborate potential actions, which shall tackle this prevailing hindrance by promoting the harmonisation of information systems for traffic and infrastructure management.

In the future, also the intermodal transport sector will have suitable ICT-based systems and applications easing day-to-day working activities in the fields of transport planning and transport monitoring. Same as intermodal transport monitoring, also intermodal transport planning lacks in existing services and ICTtools helping to constitute a comprehensive transport chain comprising numerous processes and interfaces. Probably the main reason why intermodal transport systems are not in place, are the missing links among the different transport modes and all involved business enterprises and organisations.

Therefore, interfaces between the transport modes are most critical variable, whereas both physical and electronic interfaces have to be improved in order to enable seamless cargo and information flows across all modes. Intermodal Tracking and Tracing (T\&T) solutions are best practice examples for increasing the transparency and the degree of steering of intermodal transport chains en route. Intermodal transport planning systems and ICTapplications are good examples for easing the generation of transport chains, which can directly contribute an increased usage and promotion of sustainable surface transport modes (rail, inland waterway, short sea shipping) rely on multi- and/or intermodal system approaches.

The presented Logistics Chain Generator was designed to cover the most critical aspects of a needed ICT-application for planning and promoting intermodal transport chains. Such ICT tools can support and promote the better use of the environmentally friendly transport modes inland waterway and rail on a European stage. Especially, public presence, easy accessibility via Internet, consideration of all transport modes, links to service providers and European wide geographical coverage are preconditions for their efficiency.

\section{References}

Dijkstra, Edsger W. (1959), A note on two problems in connexion with graphs Nummerische Mathematik 1, pp. 269-271

ECO4LOG (2005 a) Report 2.4, Analyses of best practice intermodal chain management services www.eco4log. de, download area, accessed 08.03.2007, p. 39 ff.

ECO4LOG (2005 b) Report 3.1, User requirements, www. eco4log.de, download area, accessed 08.03.2007, p. 32

ECO4LOG (2005 c) Report 2.3, Analyses of shipping systems of transport chain operators and service portfolio of intermodal transhipment providers, www.eco4log.de, download area, accessed 08.03.2007, pp. 33, 76

ECO4LOG (2005 d) Report 3.1, Short specification for the tools under development, www.eco4log.de, download area, accessed 08.03.2007, p. $4 \mathrm{ff}$.

ECO4LOG (2006 a), Report 4.3.2, Recommendations and Action Plan, www.eco4log.de, download area, accessed 08.03.2007, p. 9 ff.

ECO4LOG (2006 b), Report 4.1/4.2, Task 3 IT-integration of terminals, www.eco4log.de, download area, accessed 08.03.2007, p. $40 \mathrm{ff}$.

EIRAC (2005) European Intermodal Research Advisory Council, Strategic Intermodal Research Agenda 2020 (SIRA), p. 26

European Commission (2006 a), Communication from the Commission to the Council and the European Parliament, Keep Europe moving - Sustainable mobility for our continent Mid-term review of the European Commission's 2001 Transport White Paper, COM(2006) 314 final, Brussels, 22.06.2006, p. 3

European Commission (2006 b), ibid. p. 7

European Commission (2006 b), Intermodal freight terminals - in search of efficiency to support intermodality growth, Brussels, May 2006, p. 4 ff.

European Commission (2001 a), White Paper, European transport policy for 2010: time to decide, Luxembourg, 2001, ISBN 92-894-0341-1, p. 14

European Commission (2001 b), ibid. p. 16

European Commission (2001 c), ibid. p. 5

European Commission (2001 d), ibid. p. 43

Eurostat (2006), EC economic data pocketbook 3rd quarter 2006, ISSN 1026-0846, Catalogue no. KS-CZ-06-003EN-N , pages 9-10, http://epp.eurostat.ec.europa.eu (accessed 06.03.2007)

PriceWaterhouseCoopers (2007), Preparatory study for an impact assessment on a EU freight logistics action plan, Freight logistics action plan's consultation phase: stakeholders' demand for policy measures, DG TREN, April 2007 
tradav/ProgTrans (2004), Telematikeinsatz für die Hinterlandanbindung der deutschen Ostseehäfen (Use of telematics for the hinterland connectivity of the German Baltic Sea ports), Study for the German Ministry of Transport, Basel/Lübeck, p. $70 \mathrm{ff}$.

UN/ECE (2001), Terminology on combined transport, Prepared by the UN/ECE, the European Conference of Ministers of Transport (ECMT) and the European Commission (EC), United Nations, New York and Geneva

European Union (2006), Energy and transport in Figures 2006, Directorate-General for Energy and Transport in co-operation with Eurostat

\section{Literature}

Dijkstra, Edsger W. (1959), A note on two problems in connexion with graphs, Nummerische Mathematik 1

ECO4LOG (2005 a) Report 2.4, Analyses of best practice intermodal chain management services, www.eco4log. de, download area, accessed 08.03.2007

ECO4LOG (2005 b) Report 3.1, User requirements, www. eco4log.de, download area, accessed 08.03.2007

ECO4LOG (2005 c) Report 2.3, Analyses of shipping systems of transport chain operators and service portfolio of intermodal transhipment providers, www.eco4log.de, download area, accessed 08.03.2007

ECO4LOG (2005 d) Report 3.1, Short specification for the tools under development, www.eco4log.de, download area, accessed 08.03.2007

ECO4LOG (2006 a), Report 4.3.2, Recommendations and Action Plan, www.eco4log.de, download area, accessed 08.03.2007

ECO4LOG (2006 b), Report 4.1/4.2, Task 3, IT-integration of terminals, www.eco4log.de, download area, accessed 08.03.2007

EIRAC (2005) European Intermodal Research Advisory Council, Strategic Intermodal Research Agenda 2020 (SIRA)

European Commission (2001), White Paper, European transport policy for 2010: time to decide, Luxembourg, 2001, ISBN 92-894-0341-1

European Commission (2006 a), Communication from the Commission to the Council and the European Parliament, Keep Europe moving - Sustainable mobility for our continent Mid-term review of the European Commission's 2001 Transport White Paper, COM(2006) 314 final, Brussels, 22.06.2006

European Commission (2006 b), Intermodal freight terminals - in search of efficiency to support intermodality growth, Brussels, May 2006

European Union (2006), Energy and transport in Figures 2006, Directorate-General for Energy and Transport in co-operation with Eurostat

Eurostat (2006), EC economic data pocketbook 3rd quarter 2006, ISSN 1026-0846, Catalogue no. KS-CZ-06003-EN-N , http://epp.eurostat.ec.europa.eu (accessed 06.03.2007)
PriceWaterhouseCoopers (2007), Preparatory study for an impact assessment on a EU freight logistics action plan, Freight logistics action plan's consultation phase: stakeholders' demand for policy measures, DG TREN, April 2007

tradav/ProgTrans (2004), Telematikeinsatz für die Hinterlandanbindung der deutschen Ostseehäfen (Use of telematics for the hinterland connectivity of the German Baltic Sea ports), Study for the German Ministry of Transport, Basel/Lübeck

UN/ECE (2001), Terminology on combined transport, Prepared by the UN/ECE, the European Conference of Ministers of Transport (ECMT) and the European Commission (EC), United Nations, New York and Geneva

\section{Authors}

Dipl.-Ing. Bertram Meimbresse

Technische Fachhochschule Wildau

FB Ingenieurwesen/Wirtschaftsingenieurwesen

Verkehrslogistik

Tel. +493375 508-355

bertram.meimbresse@tfh-wildau.de

\section{Dr. Gerhard Schilk}

via donau

Österreichische Wasserstraßen-Gesellschaft mbH

Donau-City-Straße 1, A-1220 Vienna

Tel. +435043211621

gerhard.schilk@via-donau.org

Prof. Dr.-Ing. Herbert Sonntag

Technische Fachhochschule Wildau

FB Ingenieurwesen/Wirtschaftingenieurwesen

Verkehrslogistik

Tel. +49 3375 508-924

herbert.sonntag@tfh-wildau.de 